\title{
PENGARUH STRATEGI PEMBELAJARAN DAN GAYA BELAJAR TERHADAP HASIL BELAJAR AL-QUR'AN HADIST
}

\author{
Hudaibiah $^{2}$ dan Sahat Siagian' \\ RSMPBIM Yayasan Pendidikan Shafiyyatul Amaliyah Medan ${ }^{1}$ dan Universitas Negeri Medan ${ }^{2}$ \\ uday_tp@yahoo.com ${ }^{1}$ dan Sahat.sgn61@gmail.com ${ }^{2}$
}

\begin{abstract}
Abstrak: Penelitian ini bertujuan untuk: (1) mengetahui perbedaan hasil belajar siswa yang diajar dengan strategi pembelajaran berbasis Quantum Learning dan strategi pembelajaran ekspositori, (2) mengetahui perbedaan hasil belajar Al-Qur'an Hadist antara siswa yang memiliki Gaya Belajar Visual dan Gaya Belajar Auditori, (3) mengetahui interaksi antara strategi pembelajaran dan gaya belajar dalam mempengaruhi hasil belajar Al-Qur'an Hadist siswa. Metode penelitian quasi eksperimen dengan statistik deskriptif menggunakan Anava 2 jalur pada taraf signifikan $\square=$ 0,05 , terlebih dahulu dilakukan uji persyaratan analisis data yaitu uji normalitas dengan uji Lilliefors dan uji homogenitas varians dengan uji Bartlett dan Uji Fisher. Hasil penelitian menunjukkan bahwa: (1) hasil belajar Al-Qur'an Hadist siswa yang dibelajarkan dengan strategi pembelajaran berbasis Quantum Learning lebih tinggi dibandingkan strategi pembelajaran ekspositori. $F_{\text {hitung }}=105,78>F_{\text {tabel }}=3,95$; (2) siswa yang memiliki gaya belajar visual memperoleh hasil belajar Al-Qur'an Hadist yang lebih tinggi dibandingkan gaya belajar auditori. Hal ini ditunjukkan oleh $F_{\text {hitung }}=5,46>F_{\text {tabel }}=3,95$, dan (3) terdapat interaksi antara strategi pembelajaran dan gaya belajar dalam mempengaruhi hasil belajar Al-Qur'an Hadist siswa. Hal ini ditunjukkan oleh $F_{\text {hitung }}=34,99>F_{\text {tabel }}=3,95$.
\end{abstract}

Kata Kunci: strategi pembelajaran, gaya belajar, hasil belajar al-qur'an hadist

Abstract: This study aims to: (1) determine differences in learning outcomes of students who are taught by Quantum Learning-based instructional strategies and learning strategies expository, (2) determine differences in learning outcomes of the Qur'an Hadith between students who have a Visual Learning Styles and Style Auditory learning, (3) the interaction between learning strategies and learning styles in affecting learning outcomes of the Qur'an Hadith students. Quasiexperimental research methods with descriptive statistics using Anova 2 lanes at significant level $\alpha$ $=0.05$, first tested the data analysis requirements that normality test with Lilliefors test and test homogeneity of variance with Bartlett test and Fisher test. The results showed that: (1) the results of study of the Qur'an Hadith students that learned with a learning strategy based Quantum Learning is higher than expository teaching strategy. $F c=105.78>F t=3.95$; (2) students who have a visual learning styles acquire the learning outcomes of the Qur'an Hadith higher than auditory learning style. This is demonstrated by $F c=5.46>F t=3.95$, and (3) there is interaction between learning strategies and learning styles in affecting learning outcomes of the Qur'an Hadith students. This is demonstrated by $F c=34.99>F t=3.95$.

Keywords: learning strategies, learning styles, learning outcomes quran hadith

\section{PENDAHULUAN}

Pendidikan juga mendorong sikap individual kearah efektifitas, integritas dan sikap komunal kearah rasional dan fungsional. Dengan demikian, pendidikan mempunyai pengaruh inovatif terhadap kondisi masyarakat dalam rangka meningkatkan kualitas SDM, menuju sistem sosial yang dinamis serta modernisasi masyarakat, ditengah perkembangan dunia saat ini. Era globalisasi mambawa dampak yang signifikan terhadap perubahan-perubahan tata nilai kehidupan masyarakat. Salah satu bentuk perubahan tata nilai tersebut adalah lemahnya keyakinan keagamaan, sikap individualistis, materialistis dan hedonistis. Keadaaan ini berlawanan dengan ajaran Islam sekaligus tidak mendukung pencapaian tujuan pendidikan nasional.

Kondisi kurang objektif terlihat pada data hasil penelitian, seperti yang dikemukakan oleh (Salamah, 2010) terungkap bahwa proses belajar mengajar Agama Islam khususnya madrasah-madrasah menengah pertama 
(MTsN) maupun SMP belum dilaksanakan secara optimal, sehingga perannya sebagai mata pelajaran yang berorientasi pada pembentukan nilai-nilai keimanan dan ketaqwaan kepada Allah SWT serta akhlak mulia belum dapat dicapai.

Beberapa hal yang menyebabkan rendahnya hasil belajar pendidikan agama khususnya Al-Qur'an dan Hadist dalam membentuk peserta didik yang beriman dan bertaqwa kepada Allah SWT serta berakhlak mulia adalah: (1) Al-Qur'an dan hadist selama ini dilaksanakan menggunakan pendekatan pembelajaran yang kurang sesuai dengan tujuan yang hendak dicapai. (2) Materi pembelajaran Al-Qur'an dan hadist yang lebih banyak bersifat teori, terpisah-pisah, terisolasi atau kurang terkait dengan mata pelajaran lain dan bahkan antar sub mata pelajaran PAI itu sendiri, yakni antara unsur Keimanan, Akhlak, Fiqih dan Sejarah Islam (Tarikh Islam) yang disajikan sendiri-sendiri. (3) Strategi pembelajarannya bersifat konvensional yakni lebih menekankan pada pengayaan pengetahuan. (Salamah, 2010)

Selain itu beberapa faktor yang mempengaruhi rendahnya penguasaan nilai dan pembelajaran ini, salah satunya disebabkan karena situasi atau kondisi belajar yang menimbulkan ketegangan sehingga mempengaruhi pemerolehan nilai-nilai kehidupan yang dipelajari. Dalam pengajaran ilmu sosial perlu diperhatikan pendekatan apa yang paling sesuai untuk diberikan pada kegiatan pembelajaran. Membelajarkan nilainilai Al-Qur'an dan hadist di lingkungan MTsN maupun SMP tidaklah semudah saat seseorang memberikan materi pelajaran yang lain. Latar belakang siswa yang beragam atau lingkungan keluarga dan sekitar yang baik dan buruk akan sangat memiliki pengaruh dalam pembentukan karakter seorang anak tersebut. Pembelajaran sosial dan keagamaan perlu didekatkan dengan kondisi budaya dan gambaran telah terjadinya degradasi perilaku yang memprihatinkan, sehingga saat seseorang mempelajari ilmu AlQur'an dan hadist, ia dapat memahami secara mendalam betapa pentingnya ia mengetahui pelajaran tersebut.

Menurut Dick \& Carey (2006), seorang guru hendaknya mampu untuk mengenal dan mengetahui karakteristik siswa, sebab pemahaman yang baik terhadap karakteristik siswa akan sangat berpengaruh terhadap keberhasilan proses belajar siswa. Apabila seorang guru telah mengetahui karakteristik peserta didiknya, maka selanjutnya guru dapat menyesuaikan strategi pembelajaran yang sesuai dengan karakteristik siswa tersebut.

Gagne (1977) mendefinisikan belajar sebagai perubahan dalam disposisi melalui usaha yang sungguh-sungguh yang dilakukan dalam waktu tertentu dan bukan karena proses pertumbuhan. belajar adalah suatu proses dimana suatu organisme berubah prilakunya sebagai akibat pengalaman. Dengan kata lain bahwa belajar merupakan perubahan yang terjadi karena adanya usaha dan penguatan terhadap suatu bentuk pengetahuan dan informasi yang dilakukan secara teratur. Selanjutnya Gagne dan Briggs (1979) menyatakan bahwa tujuan pengajaran dapat dipandang sebagai hasil belajar (learning outcomes), yaitu kemampuan-kemampuan yang dimiliki siswa setelah mengikuti suatu pengajaran.

Hamalik (2006) mengatakan pembelajaran adalah suatu proses terjadinya interaksi antara siswa dengan guru dalam upaya mencapai tujuan pembelajaran yang berlangsung dalam satu lokasi dan jangka waktu tertentu. Proses pembelajaran berlangsung melalui tahap-tahap persiapan, pelaksanaan dan evaluasi dalam upaya mencapai tujuan kompetensi yang selanjutnya dirumuskan dalam bentuk tujuan-tujuan pembelajaran.

Syah (2008) memberikan batasan definisi belajar yang menyinggung teori belajar Gagne dan Skinner. Ia juga membatasi belajar dengan dua rumusan yaitu (1) Belajar adalah perolehan perubahan tingkah laku yang relatif menetap sebagai akibat latihan dan pengalaman, (2) Belajar ialah proses memperoleh responrespon sebagai akibat adanya latihan khusus.

Belajar merupakan kegiatan mengingat informasi (retensi) retensi melibatkan system penyimpanan, memori dan pengorganisasian pengetahuan, belajar juga melibatkan konsentrasi yang dilakukan secara aktif dan sadar serta bereaksi pada kejadian yang terjadi diluar ataupun dalam organisme. Belajar juga melibatkan kegiatan berupa latihan pada intinya apapun bentuk kegiatannya belajar adalah perubahan tingkah laku yang bersifat menetap, meskipun sibelajar lupa akan apa yang dipelajarinya (Brown, 1987)

Hasil belajar diperoleh setelah seseorang mengikuti kegiatan atau proses pembelajaran dalam waktu tertentu. Menurut Gagne (1977) perubahan perilaku sebagai hasil belajar disebut juga dengan kemampuan yang 
meliputi:

kemampuan

informasi
untuk

verbal, yaitu mengungkapkan pengetahuan dalam bentuk bahasa lisan maupun tertulis, pemilikan informasi verbal memungkinkan individu berperan dalam kehidupan.(2) keterampilan intelektual, yaitu kemampuan yang berfungsi untuk berhubungan dengan lingkungan hidup serta mempersentasekan konsep dan lambing. Keterampilan intelektual ini terdiri dari diskriminasi jamak,dan konsep konkrit,serta prinsip; (3) siasat kognitif, yaitu kemampuan untuk menyalurkan dan mengarahkan aktifitas berfikir untuk memecahkan masalah.(4) keterampilan motorik, yaitu kemampuan melakukan serangkaian gerak jasmani dalm melakukan sesuatu secara terkoordinasi. Sehingga terwujud otomatisasi gerak jasmani; dan (5) sikap, yaitu kemampuan menerima atau menolak objek berdasarkan penilaian terhadap objek tersebut. Kelima kemempuan ini merupakan hasil interaksi antara kondisi internal siswa yang berupa potensi belajar dengan kondisi eksternal yang berupa rangsangan dari lingkungan melalui proses kognitif siswa. Romizowski (1981) menyatakan bahwa hasil belajar diperoleh dalam bentuk pengetahuan dan keterampilan. Pengetahuan dikelompokan pada empat kategori. (1) Fakta, merupakan pengetahuan tentang objek nyata, hubungan dari keyataan, dan informasi verbal dari suatu objek, peristiwa atau manusia. (2) Konsep, merupakan pengetahuan tentang seperangkat objek konkrit atau defenisi. (3) Prosedur, merupakan pengetahuan tentang tindakan demi tindakan yang bersifat linier dalam mencapai suatu tujuan.(4) Prinsip,

Anderson, $\mathrm{dkk}$

mengklasifikasikan hasil belajar dalam tiga ranah yaitu ranah kognitif, afektif dan psikomotorik. Ranah kognitif terbagi dalam enam tingkatan yaitu ingatan, pemahaman, aplikasi, analisis, evaluasi dan kreativitas. Ranah afektif terbagi menjadi lima tingkatan yaitu penerimaan, penganggapan, penghargaan, pengorganisasian dan penjatidirian. Ranah psikomotorik terbagi menjadi empat tingkatan yaitu peniruan, manipulasi, artikulasi, dan

Dick \& Carey (2005) menambahkan bahwa strategi pembelajaran memuat lima komponen utama yaitu: (1) aktivitas pembelajaran pendahuluan, (2) penyampaian informasi, (3) partisipasi peserta didik, (4) tes, (5) kegiatan lanjutan. Selanjutnya Suparman (2001) mendefinisikan strategi pembelajaran sebagai perpaduan dari : (1) urutan kegiatan instruksional, (2) cara pengorganisasian materi pengajaran dan peserta didik, (3) peralatan dan bahan, dan (4) waktu yang digunakan dalam proses pembelajaran. Kedua defenisi yang dikemukakan para ahli tersebut pada prinsipnya lebih menekankan pada aspek komponen dan prosedur pengajaran.

Romizowski (1981) juga berpendapat bahwa strategi pembelajaran merupakan suatu pendekatan menyeluruh yang dapat dibedakan menjadi dua strategi dasar yaitu penjelasan dan penemuan. Kedua strategi ini dapat dipandang sebagai dua ujung yang sejalan dalam suatu kontinum strategi. Hal ini erat kaitannya dengan pendekatan deduktif dimana strategi ini dimulai dengan penyajian informasi mengenai prinsip atau kaidah kemudian diikuti tes penguasaan dan penerapan dalam bentuk contoh.

Dimyati (2006) menjelaskan untuk mengoptimalkan interaksi peserta didik dengan komponen sistem pembelajaran lainnya, tenaga pengajar harus mengkonsistensikan tiap aspek komponen yang membentuk sistem dan dapat melakukan hal tersebut dengan berbagai siasat. Kegiatan tenaga pengajar mengupayakan konsistensi antara aspek komponen pembentuk sistem pembelajaran dengan siasat tertentu inilah disebut dengan istilah strategi pembelajaran.

$$
\text { Reigeluth dan Merill (1989) }
$$

mengajukan tiga komponen utama teori pembelajaran yaitu : strategi, kondisi dan hasil. Yang dimaksud dengan strategi pembelajaran adalah berbagai macam cara untuk mencapai berbagai macam hasil dalam berbagai macam kondisi. Kondisi pembelajaran merupakan faktor yang mempengaruhi dampak strategi, dan karena itu penting untuk menentukan strategi. Hasil pembelajaran merupakan berbagai akibat yang dapat dipakai untuk mengukur kegunaan berbagai macam strategi dalam berbagai kondisi.

Dick and Carey (1990), mengatakan bahwa strategi pembelajaran adalah penjelasan komponen-komponen umum dari suatu set bahan pembelajaran dan prosedur-prosedur yang akan digunakan bersama bahan-bahan tersebut untuk menghasilkan hasil belajar tertentu pada siswa. Sedangkan Romizowsky (1981) menyatakan bahwa setiap strategi pembelajaran yang dikembangkan selalu mencerminkan posisi teoritis yang dianut tentang bagaimana seharusnya pembelajaran dilaksanakan. Berdasarkan pendapat ini maka strategi pembelajaran adalah penentuan cara penyampaian materi dan penetapan urutan 
kegiatan siswa dan guru pada proses pembelajaran. Sedangkan Pada definisi ini ternyata bahwa, strategi pembelajaran tidak hanya terbatas pada prosedur kegiatan melainkan juga termasuk didalamnya materi atau paket pembelajaran komponen pendukung lainnya. Beliau menyebutkan lima komponen umum dari strategi pembelajaran yaitu : kegiatan pra pembelajaran, penyajian informasi, partisipasi siswa, tes, dan tindak lanjut. Semua komponen diusahakan untuk membantu memudahkan siswa mencapai tujuan.

Gerlach dan Ely (1990), Menyatakan strategi pembelajaran adalah merupakan caracara yang dipilih untuk menyampaikan materi pelajaran dalam lingkungan pengajaran tertentu, yang meliputi lingkup dan urutan kegiatan yang dapat memberikan pengalaman belajar kepada siswa. Strategi pembelajaran dapat diartikan sebagai perencanaan yang berisi tentang rangkaian kegiatan yang didesain untuk mencapai tujuan pendidikan tertentu (Sanjaya, 2008). Strategi pembelajaran adalah cara yang akan digunakan oleh pengajar untuk memilih kegiatan belajar yang akan digunakan selama proses pembelajaran. Pemilihan tersebut dilakukan dengan mempertimbangkan situasi dan kondisi, sumber belajar, kebutuhan dan karakteristik peserta didik yang dihadapi dalam rangka mencapai tujuan pembelajaran tertentu. Secara umum strategi pembelajaran terdiri dari lima komponen yang saling berinteraksi dengan karakter fungsi dalam mencapai tujuan pembelajaran, yaitu: (1) kegiatan pembelajaran pendahuluan, (2) penyampaian informasi, (3) partisipasi peserta didik, (4) tes, dan (5) kegiatan lanjutan. (Uno, 2010).

Mukhtar (2010) menyatakan bahwa strategi pembelajaran merupakan perpaduan dari urutan kegiatan, cara pengorganisasian materi pelajaran dan siswa, peralatan dan bahan, serta waktu yang digunakan dalam proses pembelajaran untuk mencapai tujuan pembelajaran yang ditentukan. Dengan kata lain, strategi pembelajaran disebut sebagai prosedur yang sistematik dalam mengkomunikasikan isi pelajaran kepada siswa untuk mencapai tujuan pembelajaran tertentu. Rumusan strategi pembelajaran tidak hanya sekedar urutan kegiatan dan metode pembelajaran saja. Didalamnya terkandung pula media pembelajaran dan alokasi waktu untuk setiap langkah kegiatan tersebut.

Sedangkan menurut Miarso (2007) setiap rumusan strategi pembelajaran mengandung sejumlah unsur atau komponen.
Kombinasi di antara unsur-unsur itu boleh dikatakan tidak terbatas. Unsur-unsur yang lazim terdapat dalam rumusan strategi pembelajaran adalah: (1) tujuan umum pembelajaran yang ingin dicapai, (2) teknik yaitu; berbagai macam cara yang dapat dilakukan untuk mencapai tujuan umum, (3) pengorganisasian kegiatan belajar mengajar, (4) peristiwa pembelajaran, yaitu penahapan dalam melaksanakan proses pembelajaran termasuk usaha yang perlu dilakukan dalam tiap tahap agar proses itu berhasil, (5) urutan belajar, yaitu penahapan isi ajaran yang diberikan agar lebih mudah dipahami, (6) penilaian, yaitu alat (instrumen) yang digunakan untuk mengukur usaha dan atau hasil belajar, (7) pengelolaan kegiatan belajar/kelas, yaitu bagaimana pola pembelajaran diselenggarakan, (8) tempat/latar adalah lingkungan dimana proses belajar mengajar berlangsung, dan (9) waktu, jumlah dan saat/jadwal berlangsungnya

Strategi Pembelajaran berbasis Quantum learning sebagai salah satu strategi yang mengkonsentrasikan pada ketrampilan guru dalam merancang, mengembangkan, dan mengelola sistem pembelajaran sehingga guru mampu menciptakan suasana pembelajaran yang efektif, menggairahkan, dan memiliki keterampilan hidup (DePorter, 2004). Sehingga strategi pembelajaran berbasis quantum learning ini merupakan bentuk inovasi pengubahan bermacam-macam interaksi yang ada didalam dan disekitar momen belajar. Interaksi-interaksi ini mencakup unsur-unsur belajar efektif yang mempengaruhi kesuksesan siswa dalam belajar. Dari proses interaksi yang dilakukan mengubah kemampuan dan bakat alamiah siswa menjadi cahaya yang akan bermanfaat bagi mereka dan orang lain.

Sanjaya (2006) mengemukakan ciri pembelajaran ekspositori adalah pembelajaran yang menekankan kepada proses penyampaian materi secara verbal dari seorang guru kepada sekelompok siswa dengan maksud agar siswa dapat menguasai materi pelajaran secara optimal. Pusat pembelajaran adalah guru, siswa mendengar dan mencatat seperlunya, komunikasi terjadi satu arah, dan menyamaratakan kemampuan akademik siswa. Strategi pembelajaran ekpositori umumnya berorientasi pada kegiatan yang berpusat pada guru (teacher oriented), kebanyakan siswa bersifat pasif karena hanya mendengar ceramah atau kuliah dari guru tentaang materi pelajaran yang disampaikan. Pada strategi pembelajaran 
ekpositori, siswa belajar dengan mendengarkan penjelasan guru didepan kelas dan melaksanakan tugas jika guru memberikan latihan soal-soal kepada siswa.

Strategi pembelajaran ekpositori dinamakan pula pengajaran langsung (direct instruction), strategi pembelajaran ini memerlukan perencanaan pelaksanaan yang sangat hati-hati dari pihak guru. Agar berjalan efektif, sistem pengelolaan pembelajaran yang dilakukan oleh guru harus menjamin terjadinya keterlibatan siswa dalam memperhatikan, mendengarkan, dan resitasi (Tanya jawab) yang terencana (Departemen Pendidikan nasional 2005). Sanjaya (2006) menyatakan dalam menggunakan strategi pembelajaran ekpositori, guru harus memahami dan menguasai tiga strategi agar pembelajaran dapat berjalan dengan efektif, yaitu: (1) merumuskan tujuan yang ingin dicapai, (2) menguasai materi mata pelajaran dengan baik, dan (3) mengenali situasi, kondisi dan berbagai hal yang dapat mempengaruhi proses penyampaian materi pelajaran.

Dalam strategi pembelajaran ekspositori guru memegang peranan sangat dominan, melalui strategi ini guru menyampaikan materi secara terstruktur dengan harapan materi yang disampaikan itu dapat dikuasai siswa dengan baik. kemampuan yang diharapkan seorang guru pada siswa sebagai hasil belajar dengan strategi pembelajaran ekspositori dapat memahami apa yang di terangkan guru, mampu mengingat bahan yang disajikan, menerima tugas tanpa menolak, mendapatkan hasil ujian yang baik, serta selalu bekerja dengan baik dan teratur (Sanjaya, 2006).

Salah satu karakteristik siswa yang sebaiknya diperhatikan oleh guru dalam mendesain pembelajaran yang akan dikelolanya adalah gaya belajar. Karakteristik si belajar merupakan aspek-aspek atau kualitas perseorangan. Semua orang dalam segala usia dapat benar-benar mempelajari apapun apabila dibiarkan melakukannya dengan gaya unik yang sesuai dengan kekuatan pribadi mereka sendiri (Prashnig, 2007). Dalam hal belajar, masing-masing individu memiliki kelebihan dan kekurangan dalam menyerap pelajaran yang diberikan. Oleh karena itu dalam dunia pendidikan dikenal berbagai metode untuk dapat memenuhi tuntutan perbedaan individu tersebut.

Di negara-negara maju sistem pendidikan bahkan dibuat sedemikian rupa sehingga individu dapat dengan bebas memilih pola pendidikan yang sesuai dengan karakteristik dirinya. Dunn menyatakan bahwa gaya belajar adalah cara manusia mulai berkonsentrasi, menyerap, memproses, dan menampung informasi yang baru dan sulit (Prashnig, 2007). Ada dua kategori secara umum tentang bagaimana kita belajar. Pertama, bagaimana kita menyerap informasi dengan mudah (modalitas) dan kedua, cara kita mengatur dan mengolah informasi (dominasi otak). Gaya belajar seseorang adalah kombinasi dari bagaimana ia menyerap, dan kemudian mengatur serta mengolah informasi (DePorter, 2008).

Gunawan (2007) lebih jauh menyarankan di antara tiga pendekatan yang paling popular dan sering digunakan (pendekatan berdasarkan preferensi sensori, profil kecerdasan, dan preferensi kognitif), salah satu yang disarankan adalah menggunakan gaya belajar berdasarkan pendekatan preferensi sensori. Pendekatan ini dikembangkan oleh Bandler dan Gindler, diciptakan pada tahun 1970-an. Strategi yang dikembangkan oleh Bandler dan Gindler dikenal pula dengan nama strategi Visual Auditori Auditori (VAK).

DePorter (2004) menjelaskan bahwa pada awal pengalaman belajar, salah satu di antara langkah-langkah pertama kita adalah mengenali modalitas seseorang sebagai modalitas, visual, auditori atau kinestetik (VA-K). Walaupun masing-masing dari kita belajar dengan menggunakan ketiga modalitas ini pada tahapan tertentu, kebanyakan orang lebih cenderung pada salah satu di antara ketiganya. Faktor yang menyebabkan mengapa gaya belajar layak diketahui, salah satunya adalah karena cara guru memperlakukan siswa mempengaruhi perilaku dan motivasi belajar siswa. Terkadang guru cenderung mengarahkan siswa untuk menggunakan gaya belajar yang dimilikinya, sehingga proses pembelajaran akan berlangsung dengan gaya belajar guru yang mempengaruhi gaya belajar siswa.

Slameto (2003) menyatakan bahwa gaya belajar dapat dikonsepsikan sebagai sikap, pilihan atau strategi yang stabil menentukan cara seseorang yang khas dalam menerima, mengingat, berfikir dan memecahkan masalah. Setiap siswa berbeda dalam memperoleh, menyimpan serta menerapkan pengetahuan maka tidak ada gaya belajar yang lebih baik dari yang lain, karena ketiga gaya belajar ini dimiliki oleh setiap orang. Hanya saja ada salah satu gaya belajar yang lebih dominan pada diri 
kita. Jadi, bila seseorang belajar sesuai dengan gaya belajarnya yang dominan, pelajaran akan lebih mudah diterima dan kemungkinan suksesnya juga lebih tinggi.

Adapun ciri-ciri perilaku individu dengan karakteristik cara belajar menurut DePorter \& Hernacki (2000), adalah sebagai berikut: (a) individu yang memiliki kemampuan belajar Visual, (b) individu yang memiliki kemampuan belajar Auditorial, dan (c) individu yang memiliki kemampuan belajar kinestetik. Akan tetapi pada penelitian ini hanya dibatasi pada gaya belajar visual dan auditori.

Menurut Prashnig (1998) bahwa kunci menuju keberhasilan dalam belajar dan bekerja adalah mengetahui gaya belajar atau bekerja yang unik dari setiap orang, menerima kekuatan sekaligus kelemahan diri sendiri, dan sebanyak mungkin menyesuaikan preferensi pribadi dalam setiap situasi pembelajaran, pengkajian maupun pekerjaan.

Masalah dalam penelitian ini adalah: (1) Apakah hasil belajar Al-Qur'an dan Hadist siswa yang diajar dengan strategi berbasis quantum learning lebih tinggi dari hasil belajar siswa yang diajar dengan strategi pembelajaran ekspositori?; (2) Apakah hasil belajar Al-Qur'an dan Hadist siswa yang memiliki gaya belajar visual lebih tinggi dari siswa yang memiliki gaya belajar auditori?; dan (3) Apakah terdapat interaksi antara strategi pembelajaran dengan gaya belajar terhadap hasil belajar Al-Qur'an dan Hadist?

\section{METODE}

\section{Tempat dan Waktu Penelitian}

Penelitian ini akan dilaksanakan di RSMPBIM Yayasan Pendidikan Shafiyyatul Amaliyah Medan jln setia budi no 191. Populasi penelitian adalah seluruh siswa kelas VII YPSA Medan yang terdiri dari 4 kelas, yakni VII A, VII B, VII C, VII D berjumlah 160 orang. Teknik pengambilan sampel dalam penelitian ini adalah teknik sampel kelompok secara acak (cluster random sampling). Selanjutnya melalui pengundian maka kelas VII C sebagai kelas eksperimen yang dibelajarkan dengan strategi pembelajaran berbasis quantum learning, sedangkan siswa kelas VII B sebagai kelas eksperimen yang dibelajarkan dengan strategi pembelajaran ekspositori.

Penelitian ini menggunakan metode eksperimen dengan rancangan quasi eksperimen (quasi eksperimental research method) sebab kelas yang digunakan adalah kelas yang sudah terbentuk sebelumnya. Dalam penelitian ini terdapat dua kelompok perlakuan yaitu satu kelompok sebagai kelas perlakuan strategi berbasis quantum learning dan satu kelompok lagi sebagai kelas perlakuan strategi pembelajaran ekspositori. Gaya belajar siswa dalam penelitian ini berperan sebagai variabel moderator. Variabel ini disebabkan atas gaya belajar visual dan auditori yang kegunaannya untuk melihat interaksi antara strategi pembelajaran dan gaya belajar terhadap hasil belajar.

Disain penelitian yang digunakan dalam penelitian ini adalah eksperimen dengan faktorial 2 x 2. Melalui disain ini akan dibandingkan pengaruh strategi pembelajaran berbasis quantum learning dan strategi pembelajaran ekspositori. strategi pembelajaran berbasis quantum learning dan strategi pembelajaran ekspositori diperlakukan kepada kelompok eksperimen siswa dengan gaya belajar yang berbeda. strategi pembelajaran berbasis quantum learning dan strategi pembelajaran ekspositori sebagai variabel bebas. Gaya belajar sebagai variabel moderator dan hasil belajar Al-Qur'an dan Hadist sebagai variabel terikat.

Penelitian ini dilaksanakan dengan tidak merubah alokasi belajar Al-Qur'an Hadis yang telah terjadwal disekolah, Variabelvariabel tersebut selanjutnya akan ditinjau dalam penelitian dengan disain sebagai berikut:

Tabel 1. Desain eksperimen faktorial 2 x 2

\begin{tabular}{|c|c|c|}
\hline Strategi Pembelajaran $(\mathrm{A})$ & $\begin{array}{c}\text { Berbasis quantum learning } \\
\left(\mathrm{A}_{1}\right)\end{array}$ & ekspositori $\left(\mathrm{A}_{2}\right)$ \\
\hline Gaya Belajar $(\mathrm{B})$ & $\mathrm{A}_{1} \mathrm{~B}_{1}$ & $\mathrm{~A}_{2} \mathrm{~B}_{1}$ \\
\hline Visual $\left(\mathrm{B}_{1}\right)$ & $\mathrm{A}_{1} \mathrm{~B}_{2}$ & $\mathrm{~A}_{2} \mathrm{~B}_{2}$ \\
\hline
\end{tabular}

Keterangan :

$\mathrm{A}_{1} \mathrm{~B}_{1}$ : Hasil belajar Al-Qur'an dan Hadist siswa yang yang diajar dengan strategi pembelajaran berbasis quantum learning yang memiliki Gaya Belajar Visual 
$\mathrm{A}_{1} \mathrm{~B}_{2}$ : Hasil belajar Al-Qur'an dan Hadist siswa yang yang diajar dengan strategi pembelajaran berbasis quantum learning yang memiliki Gaya Belajar Auditori

$\mathrm{A}_{2} \mathrm{~B}_{1}$ : Hasil belajar Al-Qur'an dan Hadist siswa yang diajar dengan strategi Pembelajaran ekspositori yang memiliki gaya belajar Visual.

$\mathrm{A}_{2} \mathrm{~B}_{2}$ : Hasil belajar Al-Qur'an dan Hadist siswa yang diajar dengan strategi Pembelajaran ekspositori yang memiliki belajar auditori.

Teknik statistik inferensial digunakan untuk menguji hipotesis penelitian, teknik inferensial yang digunakan adalah teknik analisis varians (ANAVA) dua jalur dengan taraf signifikan 0,05 . Uji persyaratan analisis dilakukan dengan uji normalitas menggunakan uji Lilliefors, sedangkan uji homogenitas digunakan uji Bartlett. Karena ada perbedaan dan interaksi antara variabel maka analisis dilanjutkan dengan uji Scheffe. Uji Scheffe digunakan karena banyak data dalam setiap kolom dan baris tidak sama. Selanjutnya untuk keperluan pengujian hipotesis, dirumuskan hipotesis statistik:

Hipotesis Pertama

$$
\begin{aligned}
& \mathrm{H}_{\mathrm{o}}: \mu \mathrm{A}_{1}=\mu \mathrm{A}_{2} \\
& \mathrm{H}_{\mathrm{a}}: \mu \mathrm{A}_{1}>\mu \mathrm{A}_{2}
\end{aligned}
$$

Hipotesis Kedua

$$
\begin{aligned}
& H_{o}: \mu B_{1}=\mu B_{2} \\
& H_{a}: \mu B_{1}>\mu B_{2}
\end{aligned}
$$

Hipotesis Ketiga

$$
\mathrm{H}_{\mathrm{o}}: \mathrm{A}><\mathrm{B}=0
$$

\section{HASIL DAN PEMBAHASAN \\ Hasil}

\begin{tabular}{|c|c|c|c|c|c|c|}
\hline SP & & $\begin{array}{l}\text { asis Quantum } \\
\text { Learning }\end{array}$ & & kspositori & & Total \\
\hline V & $\begin{array}{l}\frac{\mathrm{n}}{\mathrm{X}} \\
\Sigma \mathrm{X} \\
\Sigma \mathrm{X}^{2} \\
\mathrm{Sd} \\
\mathrm{Sd}^{2}\end{array}$ & $\begin{array}{l}=16 \\
=25,19 \\
=403 \\
=10227 \\
=2,26 \\
=5,10\end{array}$ & $\begin{array}{l}\frac{\mathrm{n}}{\mathrm{X}} \\
\Sigma \mathrm{X} \\
\Sigma \mathrm{X}^{2} \\
\mathrm{Sd} \\
\mathrm{Sd}^{2}\end{array}$ & $\begin{array}{l}=22 \\
=21,00 \\
=462 \\
=9762 \\
=1,65 \\
=2,72\end{array}$ & $\begin{array}{l}\frac{\mathrm{N}}{\mathrm{X}} \\
\Sigma \mathrm{X} \\
\Sigma \mathrm{X}^{2} \\
\mathrm{Sd} \\
\mathrm{Sd}^{2}\end{array}$ & $\begin{array}{l}=38 \\
=46,19 \\
=865 \\
=19989 \\
=3,88 \\
=3.885\end{array}$ \\
\hline A & $\begin{array}{l}\frac{\mathrm{n}}{\mathrm{X}} \\
\Sigma \mathrm{X} \\
\Sigma \mathrm{X}^{2} \\
\mathrm{Sd} \\
\mathrm{Sd}^{2}\end{array}$ & $\begin{array}{l}=24 \\
=16,96 \\
=407 \\
=7011 \\
=2,13 \\
=4,53\end{array}$ & $\begin{array}{l}\frac{\mathrm{n}}{\mathrm{X}} \\
\Sigma \mathrm{X} \\
\Sigma \mathrm{X}^{2} \\
\mathrm{Sd} \\
\mathrm{Sd}^{2}\end{array}$ & $\begin{array}{l}=18 \\
=18,78 \\
=338 \\
=6484 \\
=2,75 \\
=7,62\end{array}$ & $\begin{array}{l}\frac{\mathrm{N}}{\mathrm{X}} \\
\Sigma \mathrm{X} \\
\Sigma \mathrm{X}^{2} \\
\mathrm{Sd} \\
\mathrm{Sd}^{2}\end{array}$ & $\begin{array}{l}=42 \\
=35,74 \\
=745 \\
=13495 \\
=4,88 \\
=4.045\end{array}$ \\
\hline Total & $\begin{array}{l}\frac{\mathrm{N}}{\mathrm{X}} \\
\Sigma \mathrm{X} \\
\Sigma \mathrm{X}^{2} \\
\mathrm{Sd} \\
\mathrm{Sd}^{2}\end{array}$ & $\begin{array}{l}=40 \\
=42,15 \\
=810 \\
=17238 \\
=4,39 \\
=4.815\end{array}$ & $\begin{array}{l}\frac{\mathrm{N}}{\mathrm{X}} \\
\Sigma \mathrm{X} \\
\Sigma \mathrm{X}^{2} \\
\mathrm{Sd} \\
\mathrm{Sd}^{2}\end{array}$ & $\begin{array}{l}=40 \\
=39,78 \\
=800 \\
=16248 \\
=4,37 \\
=3.115\end{array}$ & $\begin{array}{l}\frac{\mathrm{N}}{\mathrm{X}} \\
\Sigma \mathrm{X} \\
\Sigma \mathrm{X}^{2} \\
\mathrm{Sd} \\
\mathrm{Sd}^{2}\end{array}$ & $\begin{array}{l}=80 \\
=81,93 \\
=1610 \\
=33484 \\
=8,76 \\
=7.93\end{array}$ \\
\hline
\end{tabular}

Berdasarkan analisa data secara deskriptif maka hasil yang diperoleh dapat dilihat pada tabel 2 berikut ini:

Tabel 2. Hasil Penelitian secara analisis deskriptif (Statistik Anava 2 Jalur)

Secara keseluruhan hasil Anava untuk pengujian hipotesis dapat dilihat pada Tabel 3 di bawah ini.

Tabel 3. Rangkuman Hasil Anava Secara Keseluruhan Terhadap Hasil Belajar Al-Qur'an dan Hadist

\begin{tabular}{|l|c|c|c|c|c|}
\hline \multicolumn{1}{|c|}{ Sumber Variasi } & JK & Dk & KT & $\mathrm{F}_{\text {hit }}$ & \multirow{2}{*}{ tab } \\
\cline { 1 - 5 } Baris & 27,48 & 1 & 27,48 & 5,46 & \multirow{2}{*}{3,95} \\
\hline Kolom & 532,08 & 1 & 532,08 & 105,78 & \\
\hline
\end{tabular}




\begin{tabular}{|l|c|c|c|c|c|}
\hline Interaksi & 175,99 & 1 & 175,99 & 34,99 & \multirow{2}{*}{} \\
\cline { 1 - 5 } Dalam & 382,51 & 76 & 5,03 & & \\
\cline { 1 - 5 } Total & 1117,57 & 79 & & & \\
\hline
\end{tabular}

Karena ada interaksi antara strategi pembelajaran dan Gaya Belajar dalam mempengaruhi hasil belajar Al-Qur'an dan Hadist, maka perlu dilakukan uji lanjutan (post hoc test), untuk mengetahui rata-rata hasil belajar sampel mana yang berbeda. Untuk melihat bentuk interaksi antara strategi pembelajaran dan Gaya Belajar dalam mempengaruhi hasil belajar Al-Qur'an dan Hadist, dilakukan uji lanjut dengan menggunakan uji Scheffe', seperti pada Tabel 4. berikut :

Tabel 4. Ringkasan Hasil Perhitungan Uji Scheffe'

\begin{tabular}{|c|c|c|c|c|}
\hline \multicolumn{2}{|c|}{ Hipotesis Statistik } & \multirow{2}{*}{$F_{\text {hitung }}$} & \multicolumn{2}{|c|}{$\mathrm{F}_{\text {table }}$} \\
\cline { 4 - 5 } & & $\alpha=5 \%$ & $\mathrm{~A}=1 \%$ \\
\hline Ho $: \mu \mathrm{A}_{1} \mathrm{~B}_{1}=\mu \mathrm{A}_{2} \mathrm{~B}_{1}$ & $\mathrm{Ha}: \mu \mathrm{A}_{1} \mathrm{~B}_{1}>\mu \mathrm{A}_{2} \mathrm{~B}_{1}$ & 5,69 & 2,72 & 4,05 \\
\hline Ho: $\mu \mathrm{A}_{1} \mathrm{~B}_{2}=\mu \mathrm{A}_{2} \mathrm{~B}_{2}$ & $\mathrm{Ha}: \mu \mathrm{A}_{1} \mathrm{~B}_{2}>\mu \mathrm{A}_{2} \mathrm{~B}_{2}$ & 11,37 & 2,72 & 4,05 \\
\hline Ho: $\mu \mathrm{A}_{1} \mathrm{~B}_{1}=\mu \mathrm{A}_{1} \mathrm{~B}_{2}$ & $\mathrm{Ha}: \mu \mathrm{A}_{1} \mathrm{~B}_{1}>\mu \mathrm{A}_{1} \mathrm{~B}_{2}$ & 7,98 & 2,72 & 4,05 \\
\hline Ho: $\mu \mathrm{A}_{2} \mathrm{~B}_{1}=\mu \mathrm{A}_{2} \mathrm{~B}_{2}$ & $\mathrm{Ha}: \mu \mathrm{A}_{2} \mathrm{~B}_{1}>\mu \mathrm{A}_{2} \mathrm{~B}_{2}$ & 4,98 & 2,72 & 4,05 \\
\hline Ho: $\mu \mathrm{A}_{1} \mathrm{~B}_{1}=\mu \mathrm{A}_{2} \mathrm{~B}_{2}$ & $\mathrm{Ha}: \mu \mathrm{A}_{1} \mathrm{~B}_{1}>\mu \mathrm{AB}_{2}$ & 6,10 & 2,72 & 4,05 \\
\hline Ho $: \mu \mathrm{A}_{2} \mathrm{~B}_{1}=\mu \mathrm{A}_{1} \mathrm{~B}_{2}$ & $\mathrm{Ha}: \mu \mathrm{A}_{2} \mathrm{~B}_{1}>\mu \mathrm{A}_{1} \mathrm{~B}_{2}$ & 4,74 & 2,72 & 4,05 \\
\hline
\end{tabular}

Selanjutnya, adanya interaksi antara variabel strategi pembelajaran dan Gaya Belajar terhadap hasil belajar Al-Qur'an dan Hadist siswa, maka perlu diberikan gambaran grafik adanya interaksi tersebut.

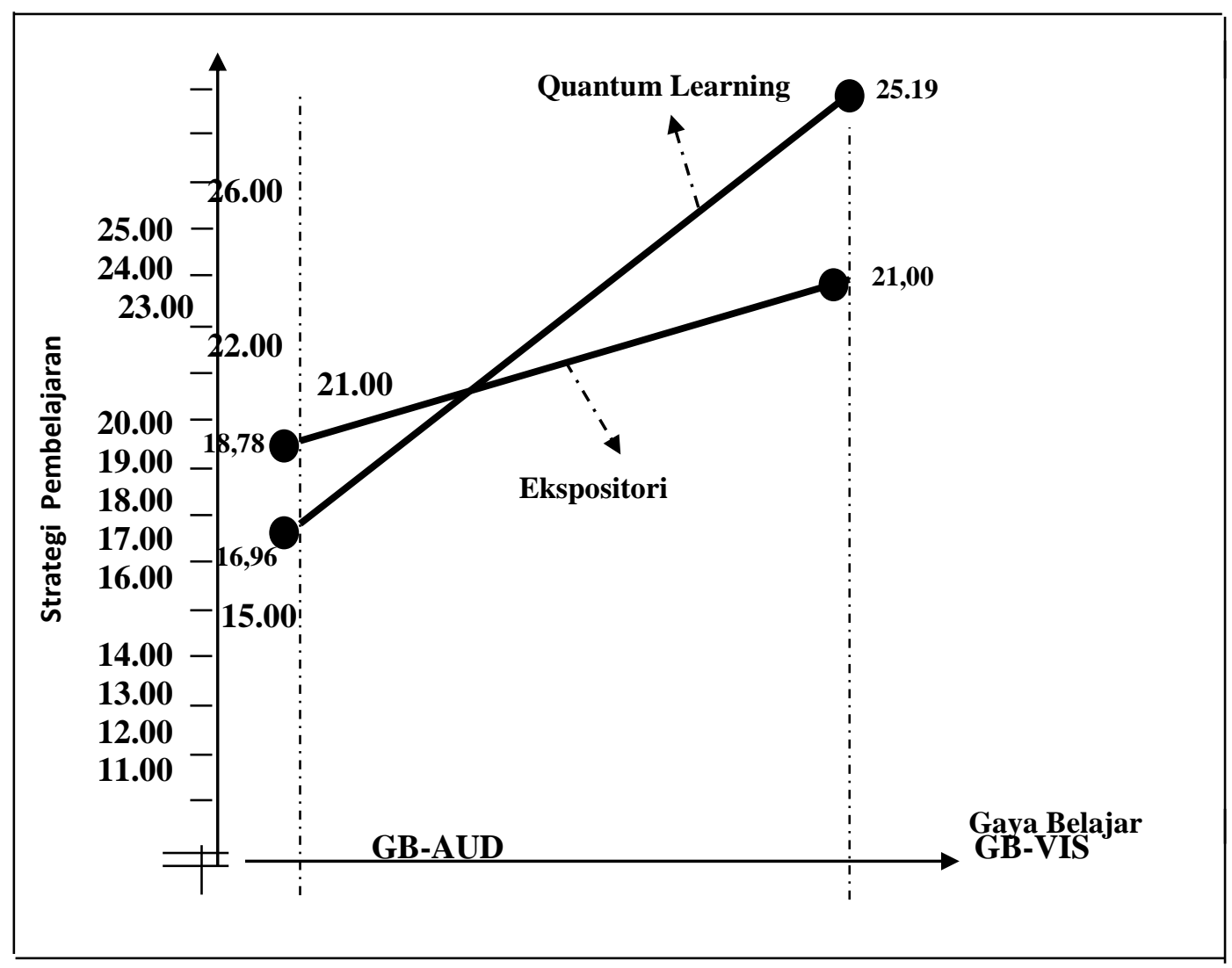

Gambar 1. Interaksi Antara Strategi Pembelajaran dan Gaya Belajar Terhadap Hasil Belajar AlQur'an dan Hadist Siswa 


\section{Pembahasan}

Strategi pembelajaran berbasis quantum learning ini pada awalnya dicetuskan oleh seorang pendidik berkebangsaan Bulgaria, yakni George Lozanov yang melakukan uji coba tentang sugesti dan pengaruhnya terhadap hasil belajar. Teorinya kemudian terkenal dengan sugestology. Menurut Lozanov, pada prinsipnya sugesti itu mempengaruhi hasil belajar. Teknik yang digunakan untuk memberikan sugesti positif dalam belajar diantaranya yaitu mendudukkan siswa secara nyaman, memasang musik di kelas atau lapangan, meningkatkan partisipasi siswa, menggunakan poster-poster dalam menyampaikan suatu informasi, dan menyediakan guru-guru yang berdedikasi tinggi. (Saefudin, 2008).

Strategi Pembelajaran berbasis Quantum learning sebagai salah satu strategi yang mengkonsentrasikan pada ketrampilan guru dalam merancang, mengembangkan, dan mengelola sistem pembelajaran sehingga guru mampu menciptakan suasana pembelajaran yang efektif, menggairahkan, dan memiliki keterampilan hidup (DePorter, 2004). Sehingga strategi pembelajaran berbasis quantum learning ini merupakan bentuk inovasi pengubahan bermacam-macam interaksi yang ada didalam dan disekitar momen belajar.

Tujuan mata pelajaran Al-Qur'an dan Hadist pada praktiknya harus dijabarkan secara fakta, konsep, generalisasi yang menyangkut pada keterampilan intelektual dan berpikir sampai berpikir kreatif, keterampilan sikap yang membentuk nilai, kepekaan dan perasaan siswa, serta keterampilan membentuk pribadi yang beriman dalam pergaulan hidup seharihari. Dalam memecahkan berbagai permasalahan agama di masyarakat maupun lingkungannya, siswa harus memiliki kemampuan untuk menyikapi masalah tersebut dengan bijak sesuai dengan petunjuk AlQur'an.

Pelajaran Al-Qur'an dan Hadist mempunyai peranan yang sangat penting, sehingga dalam memahami materi pelajaran AlQur'an dan Hadist, semua pengetahuan harus dirangkai dalam suatu sistem yang saling berhubungan. Dengan demikian, untuk merangkai materi-materi pelajaran tersebut agar saling berhubungan, seorang siswa membutuhkan kemampuan menyerap informasi dengan baik dan tepat. Kemampuan menyerap informasi dalam diri siswa akan memberikan peluang kepada siswa tersebut untuk membentuk atau melakukan pengolahan informasi dan pengetahuan siswa, yang pada gilirannya akan tiba pada pengertian yang mendalam. Selanjutnya, dengan kemampuan menyerap informasi tersebut, proses penyampaian suatu pesan atau pertukaran informasi oleh seseorang kepada orang lain akan dapat mengubah sikap, pendapat, atau perilaku seseorang baik langsung, maupun tak langsung

Siswa yang memiliki gaya belajar auditori dalam menangani masalah berpijak pada prosedur, memperdebatkan masalah, mengatasi solusi verbal, berbicara dengan kecepatan sedang. Suka berbicara bahkan didalam kelas. Mengedepankan komunikasi verbal, cenderung mengingat lebih baik dan menghafal kata-kata dan gagasan-gagasan yang pernah diucapkan. Merespon lebih bagus ketika mendengar informasi dari pada membaca.

Gaya belajar auditorial adalah belajar dengan berbicara dan mendengar. Pikiran auditori seseorang lebih kuat dari pada yang ia sadari. Telinga manusia akan terus menangkap dan menyimpan informasi auditori, bahkan tanpa disadari. Ketika seseorang membuat suara sendiri dengan berbicara, maka beberapa area penting dalam otak akan menjadi aktif. Bangsa Yunani kuno dalam filosofinya mengemukakan bahwa "jika kita mau belajar lebih banyak tentang apa saja, maka bicarakanlah tanpa henti”. Gaya belajar auditorial merupakan cara belajar standar bagi semua masyarakat sejak awal sejarah. Gaya belajar ini mengakses segala jenis bunyi dan kata yang diciptakan maupun diingat. Musik, nada, irama, dialog internal dan suara menonjol di sini. Seseorang yang sangat auditorial akan memiliki ciri-ciri antara lain: perhatiannya mudah terpecah, berbicara dengan pola berirama, belajar dengan cara mendengarkan, menggerakkan bibir atau bersuara saat membaca.

Sebaliknya Siswa yang memiliki gaya belajar visual belajar dengan melihat, mengamati dan memperhatikan. Ketajaman visual, meskipun lebih menonjol pada sebagian orang, namun sangat kuat dalam diri setiap orang. Alasannya adalah bahwa dalam otak terdapat lebih banyak perangkat untuk memproses informasi visual daripada semua indera yang lain. Gaya belajar ini mengakses citra visual yang diciptakan maupun diingat. warna, hubungan ruang, potret mental dan gambar. Seseorang yang sangat visual akan memiliki ciri khusus, diantaranya: teratur, mengingat dengan gambar, lebih suka membaca 
daripada dibacakan, serta lebih mengingat apa yang dilihat dari pada yang didengar.

Sedangkan pembelajaran Al-Qur'an dan Hadist dengan menggunakan strategi pembelajaran ekspositori, memiliki langkahlangkah pembelajaran sebagai berikut; (1) apersepsi pada pendahuluan; (2) kegiatan pokok yaitu uraian materi di mana kegiatan guru biasanya dilakukan dengan metode ceramah; (3) penutup dengan mengadakan rangkuman, kesimpulan, penilaian, dan tindak lanjut terhadap mata pelajaran yang telah diberikan. Pada pembelajaran eksposiori, proses pembelajaran hanya disajikan di dalam kelas, dilaksanakan kepada kelompok sebagai keseluruhan dan siswa belajar melalui pemahaman, sehingga sulit mengidentifikasi bakat, minat, dan kemampuan siswa. Hal ini senada dengan yang dikemukakan Strategi pembelajaran ekspositori merupakan pendekatan pembelajaran yang berorientasi pada guru, artinyu guru merupakan satu-satunya sumber informasi dan pengetahuan siswa (teacher centre). Strategi pembelajaran ini berorientasi pada guru dan biasanya ceramah menjadi pilihan utama metode pembelajarannya. Kondisi seperti ini akan mengakibatkan siswa kurang diberdayakan dalam menemukan ilmu pengetahuan yang dibutuhkannya, sebab siswa memperoleh ilmu dan pengetahuan tersebut berdasarkan apa yang disampaikan oleh gurunya saja. Senada dengan hal itu Dick and Carey (1990) mengemukakan bahwa strategi pembelajaran ekspositori cenderung menggunakan hapalan-hapalan dan lebih mengarah ke aspek memorization, yang menitikberatkan unsur ingatan, sehingga siswa memperoleh pengetahuan dan keterampilan dangan cara menghubungkan kata-kata dengan subjek secara berulang-ulang, yang pada akhirnya bila siswa belum hapal dengan sempurna, maka materi tersebut tidak dapat diteruskan atau ditambah. Dalam strategi ini, guru yang lebih banyak berperan artinya siswa tidak terlibat secara langsung dalam mencari dan menemukan materi-materi penting pembelajaran, sehingga pengetahuan dan keterampilan yang diperoleh tidak mampu meningkatkan retensi dan daya ingat siswa atau hanya berada dalam memori ingatan jangka pendek saja. Akhirnya, keberhasilan siswa dalam belajar amat tergantung pada penyampaian guru, kemampuan, dan pengalaman guru saja. Pembelajaran seperti ini akan berpotensi untuk memberikan perolehan hasil belajar yang kurang maksimal. Jadi, jelaslah bahwa strategi pembelajaran ekspositori merupakan strategi yang digunakan guru untuk menyampaikan materi pelajaran secara lisan tentang fakta-fakta, teori atau prinsip pada siswa, tanpa ikut melibatkan siswa dalam kegiatan aktif. Siswa bertindak sebagai pihak yang pasif, hanya mendengarkan ceramah guru, sehingga komunikasi hanya merupakan komunikasi satu arah.

DePorter (2004) menjelaskan bahwa pada awal pengalaman belajar, salah satu diantara langkah-langkah pertama kita adalah mengenali modalitas seseorang sebagai modalitas , visual, auditori atau kinestetik. Walaupun masing-masing dari kita belajar dengan menggunakan ketiga modalitas ini pada tahapan tertentu, kebanyakan orang lebih cenderung pada salah satu di antara ketiganya. Faktor yang menyebabkan mengapa gaya belajar layak diketahui, salah satunya adalah karena cara guru memperlakukan siswa mempengaruhi perilaku dan motivasi belajar siswa. Terkadang guru cenderung mengarahkan siswa untuk menggunakan gaya belajar yang dimilikinya, sehingga proses pembelajaran akan berlangsung dengan gaya belajar guru yang mempengaruhi gaya belajar siswa.

Hasil belajar siswa dipengaruhi oleh kualitas pembelajaran dan karakteristik siswa yang belajar. Dengan demikian, guru sebagai orang yang bertanggungjawab dalam berhasilnya proses pembelajaran harus memperhatikan satu aspek yakni karakteristik siswa yang diajarnya. Sesuai dengan hasil penelitian, bahwa siswa yang memiliki gaya belajar visual lebih tinggi hasil belajarnya jika diajar dengan strategi pembelajaran berbasis quantum learning dibandingkan jika diajar dengan strategi pembelajaran ekpositori, dan siswa yang memiliki gaya belajar auditori lebih tinggi hasil belajarnya jika diajar dengan strategi pembelajaran ekpositori dibandingkan diajar dengan strategi pembelajaran berbasis quantum learning.

Tujuan umum pembelajaran Al-Qur'an dan Hadist adalah untuk mengerti tentang kandungan Al-Qur'an baik itu tajwid, maupun kandungan dalam ayat-ayat Al-Qur'an juga didukung oleh Hadis yang tidak lain juga bersumber dari Al-Qur'an, sehingga diharapkan mampu membentuk sikap yang baik. Unsur utama pembelajaran Al-Qur'an dan Hadist adalah penalaran deduktif yang bekerja atas dasar asumsi, yaitu kebenaran suatu konsep atau pernyataan diperoleh sebagai akibat logis dari kebenaran sebelumnya. Sehingga kaitan 
antara konsep atau pernyataan dalam Al-Qur'an dan Hadist merupakan hal yang tidak dapat dipisahkan, yaitu materi Al-Qur'an dan Hadist dipahami melalui penalaran dan sebaliknya penalaran dipahami dan dilatih melalui kegiatan belajar Al-Qur'an dan Hadist. Dengan demikian, pembelajaran Al-Qur'an dan Hadist akan memberikan perolehan hasil belajar yang lebih baik melalui belajar bermakna, yakni pembelajaran yang mengaitkan antara kesiapan struktur kognitif atau pengalaman belajar dengan pengetahuan baru yang akan diterima siswa dengan cara menciptakan lingkungan belajar yang merangsang untuk pembelajaran kreatif.

Untuk siswa yang memiliki gaya belajar visual, akan memberikan hasil belajar yang lebih baik jika diajarkan dengan strategi pernbelajaran berbasis quantum learning, sebab gaya belajar visual yang dimiliki siswa akan membantu siswa tersebut menjawab persoalanpersoalan belajarnya. Artinya, Siswa yang memiliki gaya belajar visual belajar dengan melihat, mengamati dan memperhatikan. Ketajaman visual, meskipun lebih menonjol pada sebagian orang, namun sangat kuat dalam diri setiap orang. Alasannya adalah bahwa dalam otak terdapat lebih banyak perangkat untuk memproses informasi visual daripada semua indera yang lain. Gaya belajar ini mengakses citra visual yang diciptakan maupun diingat. warna, hubungan ruang, potret mental dan gambar.

Melalui strategi pembelajaran berbasis quantum learning memberikan kesempatan bagi siswa yang memiliki gaya belajar visual untuk menunjukkan bahwa setiap siswa layak merayakan hasil pembelajaran dengan cara seperti ini akan membantu siswa dan guru secara bersama-sama menghargai hasil pembelajaran. dengan kegiatan merayakan siswa akan merasa dihargai hail kerjanya. Sehingga diharapkan dengan pujian itu dapat memotivasi siswa untuk melakukan pembelajaran yang lebih maksimal maka hal tersebut harus dimanfaatkan secara maksimal. Dengan melakukan kegiatan demonstrasi, informasi dan keterampilan penting dibutuhkan akan disimpan dalam memori jangka panjang (long term memory), karena faktanya Wyatt dan Looper (2010) mengemukakan kemampuan rata-rata manusia mengingat dengan membaca $(10 \%)$, mendengarkan (20\%), melihat gambar, film, video, demonstrasi (30\%) terlibat dalam diskusi $(50 \%)$, menyajikan presentasi $(70 \%)$, bermain peran, melakukan simulasi dan mengerjakan hal nyata (90\%). sehingga informasi itu sulit hilang dari ingatan dan suatu saat yang diperlukan akan muncul sendiri serta dapat bermanfaat untuk menghadapi persoalanpersoalan belajar siswa.

Siswa dengan gaya belajar visual memperoleh hasil belajar Al-Qur'an dan Hadist yang lebih baik jika dibelajarkan dengan strategi pembelajaran berbasis quantum learning dibandingkan dengan stategi pembelajaran ekspositori. Gaya belajar visual menekankan pada penglihatan, artinya siswa belajar sembari melihat materi atau objek. Misalnya saat belajar Al-Qur'an Hadis tentang mencintai Al-Qur'an Hadist, siswa akan lebih paham jika menggunakan mp3 Al-Qur'an ditambah buku. Tentunya untuk mencintai AlQur'an harus bisa membaca Al-Qur'an dengan tajwid yang benar. Disamping karena dalam tiap materinya terdapat ayat Al-Qur'an yang akan dibahas. Dengan menggunakan indra penglihatannya selama belajar. Siswa yang memiliki gaya belajar visual akan jauh lebih memahami sesuatu, selain itu juga lebih menggembirakan. Siswa dengan gaya belajar visual akan kesulitan mengikuti penjelasan guru yang telalu teoritis. Ini disebabkan si visual learner jarang mengoptimalkan imajinasinya untuk mendapatkan informasi, memahami atau mengingat, mereka akan lebih mudah jika dapat melihat objeknya.

Dengan demikan, pada saat dibelajarkan dengan strategi pembelajaran berbasis quantum learning, siswa akan siswa telah memperoleh informasi terlebih dahulu apa yang akan dipelajari sebelum memperoleh nama untuk apa yang mereka pelajari. Ini diilhami bahwa otak akan berkembang pesat jika adanya rangsangan yang kompleks selanjutnya akan menggerakkan rasa keingintahuan, dan ransangan tersebut merupakan peluang sekaligus merupakan motivasi bagi siswa yang memiliki gaya belajar visual untuk memberikan dan menampilkan kinerja terbaiknya. Selain itu, proses pemercepatan pembelajaran yang dibutuhkan siswa, secara tidak langsung siswa juga sudah melakukan semacam evaluasi suatu materi pelajaran yang mampu meningkatkan retensi siswa terhadap materi pelajaran, dan dari evaluasi itu siswa melakukan feed back dalam rangka pengoptimalan pencapaian hasil belajar sesuai dengan tujuan instruksional yang telah ditetapkan.

Pemberian strategi pembelajaran berbasis quantum learning kepada siswa yang 
memiliki gaya belajar auditori akan mengakibatkan siswa tersebut merasa kesulitan dalam memecahkan masalah-masalah pembelajarannya, sebab siswa dengan gaya belajar auditori kesulitan dalam membentuk atau membangun ilmu pengetahuan dan keterampilan Al-Qur'an dan Hadist yang dibutuhkannya, sebab siswa siswa yang memiliki gaya belajar auditori biasanya ditandai dengan kecenderungan : (1) perhatiannya mudah pecah. (2) Kurang tertarik memperhatikan hal baru dilingkungan. (3) Mudah terganggu oleh keributan

Slavin (2009) menyatakan bahwa komponen pertama dari sistem memori yang dijumpai oleh informasi yang masuk adalah registrasi pengindraan. registrasi pengindraan menerima sejumlah besar informasi dari indra. Semakin banyak panca indra yang terlibat semakin besar stimulus yang dihasilkan. Demikian halnya dengan gaya belajar visual dan auditori yang melibatkan panca indra, siswa dapat melihat dan mendengar materi pelajaran yang disampaikan.

Siswa dengan gaya belajar auditori memiliki tingkat kecepatan yang rendah dalam memahami, dan memaknai materi-materi esensial pelajaran Al-Qur'an dan Hadist, karena struktur kognitif siswa dengan gaya belajar auditori membutuhkan waktu dan proses pembelajaran yang lebih lama untuk mencerna suatu materi pelajaran Al-Qur'an dan Hadist yang disajikan. Siswa dengan gaya belajar auditori akan mengalami kesulitan-kesulitan dalam menyelesaikan soal-soal Al-Qur'an dan Hadist yang dihadapinya, sebab siswa tersebut mudah terganggu oleh keributan dan perhatiannya mudah pecah dan pada akhirnya akan memberikan hasil belajar Al-Qur'an dan Hadist yang kurang maksimal.

Bagi siswa dengan gaya belajar visual, jika diajar dengan strategi pembelajaran ekspositori akan memperoleh hasil belajar yang kurang maksimal, sebab pembelajaran berbasis ekspositori berpusat pada guru (teacher centered), di mana guru berfungsi sebagai sumber utama pembelajaran. Dick and Carey (2006) mengemukakan bahwa pada pembelajaran ekspositori tekanan utama pembelajaran untuk seluruh anggota kelas. Guru mengajar kepada seluruh siswa tanpa memandang aspek individual, biologis, intelektual, dan psikologis siswa. Guru bertindak sebagai satu-satunya sumber belajar dan sekaligus sebagai penyaji isi pelajaran. Kerjasama siswa dalam mencapai tujuan pembelajaran tidak dibutuhkan. Siswa belajar menurut kapasitasnya masing-masing. Siregar (2011) mengemukakan bahwa pembelajaran ekspositori kurang memberdayakan siswa dalam mengamati dan mengenali wajah-wajah, benda-benda, bentuk-bentuk, warna-warna, detail-detail, dan pemandangan-pemandangan, serta kurang mampu untuk mengarahkan siswa ke benda-benda secara efektif dalam ruangan, sehingga siswa tidak merasakan dan tidak menghasilkan bayangan-bayangan mental dan visualisasi detail dalam benaknya. Dengan demikian, tujuan pembelajaran Al-Qur'an dan Hadist yang sudah ditetapkan oleh guru tidak dapat berjalan dengan efektif, dan tidak sesuai dengan tujuan intruksional yang telah ditetapkan.

\section{PENUTUP \\ Simpulan}

Simpulan hasil penelitian ini adalah sebagai berikut:

1. Hasil belajar Al-Qur'an dan Hadist siswa RSMPBIM Yayasan Pendidikan Shafiyyatul Amaliyah Medan yang dibelajarkan dengan strategi pembelajaran berbasis Quantum Learning lebih tinggi dibandingkan siswa yang dibelajarkan dengan menggunakan strategi pembelajaran ekpositori.

2. Siswa yang memiliki Gaya Belajar Visual memperoleh hasil belajar Al-Qur'an dan Hadist lebih tinggi dibandingkan dengan siswa yang memiliki Gaya Belajar Auditori.

3. Terdapat interaksi antara strategi pembelajaran dan Gaya Belajar dalam mempengaruhi hasil belajar Al-Qur'an dan Hadist siswa RSMPBIM Yayasan Pendidikan Shafiyyatul Amaliyah Medan. Untuk siswa yang memiliki Gaya Belajar Visual lebih efektif dalam meningkatkan hasil belajar Al-Qur'an dan Hadist menggunakan strategi pembelajaran berbasis Quantum Learning dari pada menggunakan strategi pembelajaran ekspositori. Sedangkan untuk siswa yang memiliki Gaya Belajar Auditori, ternyata strategi pembelajaran ekspositori lebih efektif dalam meningkatkan hasil belajar Al-Qur'an dan Hadist siswa, dari pada menggunakan strategi pembelajaran berbasis Quantum Learning.

\section{Saran}

Mengupayakan mutu pendidikan di RSMPBIM Yayasan Pendidikan Shafiyyatul Amaliyah Medan, dapat dikembangkan melalui 
proses pembelajaran yang bervariasi. Salah satu alternatif pengembangannya adalah melalui pemilihan strategi pembelajaran yang tepat dengan tujuan pembelajaran, materi pembelajaran, kemampuan, kondisi dan karakteristik siswa. Strategi yang dapat dipilih antara lain adalah strategi pembelajaran berbasis Quantum Learning dan ekpositori. Untuk siswa yang memiliki Gaya Belajar Visual penggunaan strategi pembelajaran berbasis Quantum Learning sangat efektif dalam memberikan hasil belajar yang diharapkan, tetapi untuk siswa yang memiliki Gaya Belajar Auditori penggunaan strategi pembelajaran ekpositori akan lebih efektif dalam memberikan hasil belajar Al-Qur'an dan Hadist.

Diharapkan kepada para guru Al-Qur'an dan Hadist atau tenaga pengajar umumnya agar senantiasa memperhatikan dan mempertimbangkan faktor Gaya Belajar siswa sebagai pijakan dalam merancang pembelajaran. Selain itu, guru perlu melakukan pengkajian yang mendalam tentang karakteristik siswa untuk dijadikan sebagai pijakan atau acuan untuk mengoptimalkan penerapan strategi pembelajaran berbasis Quantum Learning dalam pelajaran Al-Qur'an dan Hadist secara efektif dan efisien. Selanjutnya, guru diharapkan senantiasa aktif mengikuti pendidikan dan pelatihan yang bertujuan untuk meningkatkan kemampuannya dalam menyajikan proses pembelajaran yang menarik bagi siswa.

\section{DAFTAR PUSTAKA}

Anderson, Orin W and Krathwohl D (2001). A Taxonomy for Learning Teaching and assesing. New York: Longman Inc.

Brown, H. D. (2001) Teaching by principles. An interactive approach to language pedagogy. $2^{\text {nd }}$ Ed. New Jersey: prentice hall

Bloom, B. S. 1986. Taxonomy of Educational Objectives. Handbook 1: Cognitive domain. New York: David McKay.

Budiningsih, A. (2005). Belajar dan Pembelajaran. Jakarta. Bumi Aksara.

Bullard, Barbara (2004) meta music : opening the learning do or in the add mind. Jurnal of education. spring 2004 . volume 2, issue 2

Cuthbert, F, Peter. 2005. The student learning process: Learning Styles or Learning Approaches? Jurnal of Teaching in
Higher Education Vol. 10, No. 2, April 2005, pp. 235_ 249.

DePorter, B \& Hernacki, M. (2000) Quantum Learning. Membiasakan BelajarNyaman dan Menyenangkan Penerjemah: Alwiyah Abdurrahman. Cetakan VII. Bandung :KAIFA.

Dick,W dan Carey, L (2006). The Systemathic Design of Instruction. $4^{\text {th }}$. Harper Collins Publishers.

DePorter, B, Mark, dan Sarah (2000). Quantum Teaching. Bandung : Kaifa

DePorter, B. (2004). Berbasis quantum learning, Bandung: Kaifa.

Dimyati. (2006). Belajar dan Pembelajaran. Jakarta : Rineka Cipta.

Eyyam R, Meneviş I, Doğruer N (2011) An Investigation Of The Learning Styles Of Prospective Educators. TOJNED : The Online Journal of New Horizons In Education - July 2011, Volume 1, Issue 3

Franzoni, A. L., \& Assar, S. (2009). Student Learning Styles Adaptation Method Based on Teaching Strategies and Electronic Media. Educational Technology \& Society, 12 (4), 15-29.

Gagne, R. M., \& Wager, w. w (1992). Principles of instruction design.New York: Holt,Rinehalt and Winston.

Gay, L. R. 1981. Educational Reseach. USA. Charles E. merril Publishing.

Graf, S. Viola, R.S, Leo, T. Kinshuk. (2007) InDepth Analysis of the Felder-Silverman LearningStyle Dimensions. Journal of Research on Technology in Education, 2007, 40(1), xx-xxx

Gerlach, V.S. dan Ely, D.P (1990) Teaching and Media : A Systematic Aproach, Engliwood Cliffers: New jersey prentice hall.

Gunawan A.W. 2007. Born to be A Genius. Jakarta: Gramedia Pustaka.

Hamalik, (2006). Pendidikan Guru Berdasarkan Pendekatan Kompetensi. Jakarta:Bumi Aksara.

Hamzah. (2009). Model Pembelajaran : Menciptakan Proses Belajar Mengajar Yang Kreatif dan Efektif. Jakarta : Bumi Aksara.

Hidayat, (2010). Keefektifan pendekatan quantum learning dalam peningkatan nilai mata kuliah Nahwu I. jurnal saung guru: vol 1. No 2 (2010)

Ibrahim, T \& Darsono, H. (2008). Pemahaman Al-Qur'an dan Hadis I untuk kelas VII 
Madrasah Tsanawiyah. Solo: PT Tiga serangkai Pustaka Mandiri

Kocakoglu, M (2010). Determining the Learning Styles of Elementary School (1st-8th Grade). Teachers International Online Journal of Educational Sciences, 2010, 2 (1), 54-64

Mayer RE dan Massa LJ (2003) Three Facets of Visual and Verbal Learners: Cognitive Ability, Cognitive Style, and Learning Preference. Journal of Educational Psychology Copyright 2003 by the American Psychological Association, Inc. 2003, Vol. 95, No. 4, 833-846 0022 0663/03/\$12.00 DOI: $10.1037 / 0022-$ 0663.95.4.833

Meier, Dave, 2003. The Accelerated Learning Hand Book. Jakarta : Kaifa. Instruction Theories in Action. Regeluth (ed). New Jersey : Lawrence Erlbaum As.

Miarso, Y. (2007), Menyemai Benih Teknologi Pendidikan, Jakarta: Kencana Prenada Media Group.

Muhaimin dkk (2004). Kurikulum tingkat satuan pendidikan, Jakarta: Grafindo

Mukhtar dan Iskandar (2010), Desain Pembelajaran Berbasis Teknologi Informasi dan Komunikasi; sebuah orientasi baru, Jakarta: Gaung Persada Press.

Naimie Z, Siraj S, Abuzaid RA, Shagholi R (2010). Hypothesized learners' technology preferences based on learning style dimensions. TOJET: The Turkish Online Journal of Educational Technology - October 2010, volume 9 Issue 4.

Nugraheni E, Pangaribuan N. (2006) Gaya belajar dan strategi belajar mahasiswa jarak jauh: kasus di universitas terbuka Jurnal Pendidikan Terbuka dan Jarak Jauh, Voume. 7, Nomor 1, Maret 2006, $68-82$

Rahmat, J. (2005). Belajar cerdas ; belajar berbasiskan otak. Bandung: Mizan Learning

Reigeluth, C. M. 1983. Instructional Design Theory of Strategis. An Overview of Their Current Status. London: Prentice Hall.
Richmond, A. S., \& Cummings, R. (2005). Implementing Kolb's learning styles into online distance education. International Journal of Technology in Teaching and Learning, 1(1), 45-54

Rogers, C (1982). Freedom To Learn for the 80's. Colombus : Charles E. Merrill

Romizwoski, A. J. 1981. Instructional Design System, Decision Making in Course Planning and Curriculum Design. London: Kogan

Saefudin, Udin (2008). Inovasi Pendidikan. Bandung : Alfabeta.

Salamah. (2010) Pengembangan Strategi Pembelajaran Terpadu Bidang Studi Pendidikan Agama Islam Untuk Meningkatkan Akhlak Siswa pada SMU diBanjarmasin Tesis: Pasca Sarjana UPI Bandung.

Sanjaya, Wina (2008). Strategi Pembelajaran : Berorientasi Standar Proses Pendidikan. Jakarta : Kencana.

Seels, B. B \& Richey. 1994. Instructional Technology: The Defenition and Domain of Field. Washington, DC : AECT.

Slameto (2003). Belajar dan Faktor-Faktor yang Mempengaruhinya. Jakarta: Rineka Cipta.

Slavin, R. E. (2009), Psikologi Pendidikan; Teori dan Praktik, jilid 2, Jakarta: PT. Indek.

Siregar, H. M. (2011) Pengaruh Strategi Pembelajaran Berbasis Quantum Teaching dan Gaya Belajar Terhadap Hasil Belajar Geografi siswa Kelas X SMA I Madat Kab Aceh Timur.tesis pasca sarjana UNIMED. Medan

Syah, Muhibbin (2006). Psikologi Pendidikan dengan Pendekatan Baru. Bandung : Rosdakarya

Tyler R (1949) Basic Principles Of Curriculum And Instruction. Chicago: University of Chicago Press.

Uno, H.B. (2010), Perencanaan pembelajaran, Jakarta: Bumi Aksara.

Strategi Pembelajaran; Menciptakan proses belajar mengajar yang kreatif dan efektif, Jakarta: Bumi Aksara. 